\title{
Early diagnosis and management of Necrotizing Fasciitis
}

\author{
Narayanasamy Subbaraju Kannan ${ }^{1}$, Rajendiran Kannan ${ }^{2}$, Veluru Rohan ${ }^{3}$, \\ Chelliah Pachimuthu Ganesh Babu ${ }^{4}$. \\ 1,2,3,4 (Department Of General Surgery, Mahatma Gandhi Medical College \& Research Institute/ Sri Balaji \\ Vidyapeeth, Pondicherry, India.)
}

\begin{abstract}
:
Introduction: The term Necrotising Fasciitis (NF) refers to 'severe inflammation of the muscle sheath that leads to necrosis of the subcutaneous tissue and adjacent fascia'. Incidence of NF varies from $0.24-0.4$ per 100000 adults with high morbidity and mortality Early clinical suspicion, repeated aggressive wound debridement and broad spectrum antibiotics with interdisciplinary management improve the survival rate and reduce morbidity. However, early NF can be difficult to distinguish from non-necrotising soft tissue infections in the absence of severe sepsis, multi organ failure or pain. Based on the evolving cutaneous features, Wang $Y$ et al described three stages of NF. Based on various microbial flora involved, Morgan classified NF into types I-IV. Wong et al first described the laboratory risk indicator (LRINEC) for scoring the severity of NF. We are presenting a retrospective observation study of 112 cases of Necrotizing Fasciitis to analyse the methods for early diagnosis and management.

Materials and methods: All the case sheets of the patients diagnosed and treated as necrotizing fasciitis from 03-06-2014 to 12-08-2015 were retrieved from medical records department of our Medical College Hospital. From the case sheets, the patients' demographic, clinical, investigation management and morbidity \& mortality data were collected, tabulated and analysed to find out the best possible methods for early diagnosis and management of NF.

Results: The data collected in of our study are comparable with and similar to those of previous authors. Conclusion: Clinical findings to suspect / diagnose NF are neither specific nor sensitive especially in early stages. LRINEC scoring is a sensitive diagnostic tool but it is less specific. Imaging modalities are not useful in early cases. Gas in soft tissue X-ray is seen in 40\% of cases only. Negative wound culture and biopsy do not rule out NF. Bedside finger test is more specific. Extensive literature review does not show any study to suggest definitive methods for early diagnosis and management of NF. To create proper level of evidence larger prospective study is needed with set protocols for early diagnosis and specific indications for emergency operative intervention, delayed operative intervention and conservative management.
\end{abstract}

Keywords: Aggressive wound debridement, clinical staging, finger test, LRINEC scoring, microbial flora.

\section{Introduction}

Even though Hippocrates [1] described Necrotizing Fasciitis (NF) as a rapidly progressing infection of the skin and soft tissues, now the term Necrotising Fasciitis (NF) refers to 'severe inflammation of the muscle sheath that leads to necrosis of the subcutaneous tissue and adjacent fascia' [2]. Wilson coined the term necrotizing fasciitis in the 1950s to describe necrosis of the fascia and subcutaneous tissue with relative sparing of the underlying muscle [3]. Hemolytic streptococcal gangrene, Meleney ulcer, acute dermal gangrene, hospital gangrene, suppurative fasciitis, flesh eating bacterial disease and synergistic necrotizing cellulitis are other terms used to describe NF. Jones [4] in 1871 described it as "hospital gangrene" with a mortality of 46\%. Shortly afterwards, Jean-Alfred Fournier [5] described similar soft tissue infection of male perineum, now known as Fournier's gangrene which now includes necrotizing infections of women perineum also. Surgical debridement first performed by Meleney [6] in the early 1920s is still an integral part of current treatment for NF. Incidence of NF varies from $0.24-0.4$ per 100000 adults with high morbidity and mortality; early clinical suspicion, repeated aggressive wound debridement and broad spectrum antibiotics involving interdisciplinary team, improve the survival rate and reduce morbidity [1,3,4,7-10]. Many significant risk factors and co-morbidities like old age, immunocompromise, diabetes mellitus, cirrhosis liver, medical renal disease, congestive heart failure, gout, use of non steroidal anti inflammatory drugs (NSAID), pre existing skin and soft tissue infections precipitate NF and worsen the prognosis with increased morbidity and mortality [2,4,5,11-13]. However, in the absence of severe pain, sepsis or multi organ failure, it is difficult to distinguish early NF from non-necrotising soft tissue infections. Clinical features typical of a NF include agonising pain, tenderness beyond erythematous areas, blister or bullae formation, swelling of muscle compartments, which may give rise to a compartment syndrome, and rapid progression of invading microorganisms through tissue planes [14]. Wang Y et al Staged necrotising fasciitis based on the evolving cutaneous features [15] (TABLE 1). 
Table 1: Stages of necrotising fasciitis based on the evolving cutaneous features ${ }^{15}$.

\begin{tabular}{|l|l|l|}
\hline Stage 1 (early) & Stage 2 (intermediate) & Stage 3 (late) \\
\hline $\begin{array}{l}\text { Warm on palpation } \\
\text { Erythema }\end{array}$ & $\begin{array}{l}\text { Blister or bullae formation } \\
\text { (serous fluid) }\end{array}$ & Haemorrhagic bullae \\
\hline $\begin{array}{l}\text { Tenderness to palpitation } \\
\text { (extending beyond apparent } \\
\text { areas of skin involvement) }\end{array}$ & Skin fluctuance & $\begin{array}{l}\text { Skin anaesthesia } \\
\text { Crepitus }\end{array}$ \\
\hline Swelling & Skin induration & $\begin{array}{l}\text { Skin necrosis with dusky } \\
\text { discoloration progressing to } \\
\text { frank gangrene }\end{array}$ \\
\hline
\end{tabular}

Many studies by Park et al [16], Hsiao et al [17], Huang et al. [18], Frazee B et al [19], Dworkin M et al [20], Singh G et al [21], Shimizu T [22]' et al and Hakkarainen TW et al [23] have documented trauma including operative trauma with mono or polymicrobial infections, consumption of raw or undercooked seafood or injury by fish fins, seawater contamination of wounds infected with marine organisms as common aetiological factors. Many other authors [24-29] also reported similar conclusions on various spectrums of synergistic pathogenesis with polymicrobial infections including marine organisms in NF. However, there are increasing reports of NF caused by monomicrobial infection, especially in Asia [27]. Based on Various microbial flora involved, Morgan [30] classified NF into four types:

- $\quad$ Type 1 - polymicrobial infection with aerobic and anaerobic bacteria.

- Type 2 - Group A streptococcus (GAS) with or without staphylococcal infection.

- Type 3- Gram-negative monomicrobial infection (marine organisms such as Vibrio spp. and Aeromonas hydrophila)

- $\quad$ Type 4 - fungal infection such as Zygomycetes and Candidiasis.

Microbiology report from wound and blood cultures remains mandatory for the antibiotic selection over empirical treatment.

The laboratory risk indicator for NF (LRINEC) score first described by Wong et al [31] is shown in (TABLE 2).

Table 2: The laboratory risk indicator for NF (LRINEC) score $^{31}$.

\begin{tabular}{|l|l|l|}
\hline \multicolumn{1}{|c|}{ VARIABLE } & RESULT & SCORE \\
\hline C-REACTIVE PROTEIN [mg/dl] & $<150$ & 0 \\
& $\geq 150$ & 4 \\
\hline WBC $\left[\mathbf{x 1 0}^{6} / \mathrm{mm}^{3}\right]$ & $<15$ & 0 \\
& $15-25$ & 1 \\
& $>25$ & 2 \\
\hline HEMOGLOBIN [g/dl] & $>13.5$ & 0 \\
& $11-13.5$ & 1 \\
& $<11$ & 2 \\
\hline SODIUM [mmol/l] & $>135$ & 0 \\
& $\leq 135$ & 2 \\
\hline CREATININE [mmol/l] & $<160$ & 0 \\
& $\geq 160$ & 2 \\
\hline GLUCOSE [mmol/l] & $<10$ & 0 \\
& $\geq 10$ & 1 \\
\hline
\end{tabular}

Maximal scoring is 13 A score of $\leq 5$ points (stage 1$)$ indicates a low risk ( $<50 \%$ probability) of $\mathrm{NF}$ deserving conservative management; $6-7$ points (stage 2 ) indicate an intermediate risk (50\%-75\% probability) of NF where operative intervention can be delayed up to 24 hours with conservative management; $\geq 8$ points (stage 3 ) denoting a high risk (> 75\% probability) is a strong indication for early operative intervention.

We are presenting a retrospective study of 112 cases of Necrotizing Fasciitis to analyse the methods for early diagnosis and management.

\section{Aim Of The Study}

To find out the best possible methods for early diagnosis and management of NF by analysing the data collected from case sheets of NF patients included in the study.

\section{Materials And Methods}

All the case sheets of the patients diagnosed and treated as necrotizing fasciitis from 03-06-2014 to 1208-2015 were retrieved from medical records department of our Medical College Hospital. From the 112 case sheets thus included in the study, the patients' demographic, clinical, investigation, management and morbidity $\&$ mortality data were collected, tabulated and analysed to find out the best possible methods for early diagnosis and management of NF. 


\section{Results}

The data regarding sex \& age of the patients, site of NF, clinical symptoms \& signs, laboratory parameters, microbiology, type of management, major morbidity \& mortality collected from the case sheets are shown in TABLES 3-10. Bedside finger test was done only in $20 \%$ of cases with $80 \%$ positive findings. The negative results were partly due to very early stage recovered with conservative treatment and a very few patients wrongly suspected to be NF.

Table 3: Demographic data:

\begin{tabular}{|l|l|}
\hline Total number of patients enrolled & 112 \\
\hline Total number of male patients (\%) & 66.0 \\
\hline Total number of female patients (\%) & 46.0 \\
\hline Mean age of patients in years & 54.36 \\
\hline
\end{tabular}

Table 4: Co-morbidities

\begin{tabular}{|l|l|}
\hline Diabetes & $51.7 \%$ \\
\hline Peripheral vascular disease & $16.0 \%$ \\
\hline Alcoholic Liver disease & $12.5 \%$ \\
\hline No co-morbidities & $19.6 \%$ \\
\hline
\end{tabular}

Table 5: Presentation of NF according to site

\begin{tabular}{|l|l|}
\hline Site of lesion & No of patients $(\%)$ \\
\hline Head and neck & $13(11.61 \%)$ \\
\hline Extremity & $\mathbf{7 9}(\mathbf{7 0 . 5 4 \% )}$ \\
\hline Perineum & $20(17.85 \%)$ \\
\hline
\end{tabular}

Table 6: Signs and symptoms

\begin{tabular}{|l|l|}
\hline $\begin{array}{l}\text { Pain and tenderness, erythema, warmth } \\
\text { and swelling were present in all patients. }\end{array}$ & \\
\hline Other signs and symptoms: & \\
\hline Bullae & $\mathbf{4 2 . 8 \%}$ \\
\hline Crepitus & $\mathbf{2 2 . 3 \%}$ \\
\hline Skin necrosis & $38.3 \%$ \\
\hline Fever $\square\left[37 \cdot 5^{\circ} \mathrm{C}\right.$ & $\mathbf{3 2 . 1} \%$ \\
\hline Hypotension & $\mathbf{1 3 . 3} \%$ \\
\hline Gas on X-ray & $\mathbf{4 1 . 9 \%}$ \\
\hline
\end{tabular}

Table 7: LRINEC scoring

\begin{tabular}{|l|l|}
\hline$<6$ & $12.6 \%$ \\
\hline $6-8$ & $42.8 \%$ \\
\hline$\square 8$ & $44.6 \%$ \\
\hline
\end{tabular}

Table 8: Microbiology

\begin{tabular}{|l|l|}
\hline No growth in wound culture & $13.3 \%$ \\
\hline Positive wound culture & $86.6 \%$ \\
\hline Monomicrobial & $15.1 \%$ \\
\hline Polymicrobial & $71.4 \%$ \\
\hline
\end{tabular}

Table 9: Type of management

\begin{tabular}{|l|l|}
\hline Conservative & $12.6 \%$ \\
\hline Early operative intervention $(<24 \square$ h) & $44.6 \%$ \\
\hline Late operative intervention $(<24 \square$ h) & $42.8 \%$ \\
\hline
\end{tabular}

Table 10: Major morbidity and mortality

\begin{tabular}{|l|l|}
\hline Amputations & $\mathbf{3 . 5 7} \%$ \\
\hline Deaths & $\mathbf{4 . 4 6 \%}$ \\
\hline
\end{tabular}

\section{Discussion}

A conclusion section must be included and should indicate clearly the advantages, limitations, and possible applications of the paper. Although a conclusion may review the main points of the paper, do not replicate the abstract as the conclusion. A conclusion might elaborate on the importance of the work or suggest applications and extentions Even though early diagnosis and surgical intervention of NF can reduce mortality and morbidity including amputation rates, it is a major diagnostic challenge because, pathognomonic signs are absent in most of the cases [32]. But still a high index of suspicion will prompt any clinician to make early diagnosis based on clinical findings depending upon the stage of the disease at the time of presentation and 
confirm it with LRINEC scoring, imaging modalities like ultrasonography, X-ray, computerised tomography, magnetic resonance imaging, bed side finger test, biopsy from wound and culture sensitivity of blood, wound swab or needle aspirate. NF usually presents with the triad of pain, swelling and erythema $[2,3,6,8,15,16]$. Cellulitis and abscess are quiet often misdiagnosed as NF. Majority of NF patients present with severe pain out of proportion to the swelling or erythema $[6,8,12,16]$. Few other features of diagnostic importance are tenderness extending beyond the area of swelling \& erythema, due to enzymes and toxins spreading along the fascia below the skin, indistinct margins, absence of superficial lymphangitis and rapid worsening despite antibiotics usage [33]. Repeated review of the patient's condition for spread of signs and worsening symptoms will prompt the clinician to venture further. The development of bullae in the skin marks the intermediary stage. Skin necrosis is a feature of late NF [15]. The best way to diagnose NF is 'bedside finger test'. This is done by infiltrating the suspected area with local anaesthetic and cutting down to the deep fascia through $2 \mathrm{~cm}$ skin incision. If the index finger dissects the subcutaneous tissue off the deep fascia easily along the tissue plane, the test is positive. Presence of grey necrotic tissue and thrombosed vessels in the floor of incision wound, with thin, watery, foul-smelling fluid, described as dishwater pus oozing from beneath oedematous fascial plane and noncontracting muscles are other diagnostic findings in this simple test [34]. Urgent definitive surgical debridement should follow.

Treatment depends upon the stage and LRINEC scoring at the time of presentation of the disease. In stage I (LRINEC scoring $\leq 5$ ), conservative treatment may be useful with broad spectrum antibiotics subsequently replaced by appropriate ones based on culture sensitivity report, intravenous immunoglobin [35], hyperbaric oxygen [3] and other supportive measures. If there is no response or if disease worsens, switch over to operative line of management is essential. Stage II (LRINEC scoring 6-8) may be observed for not more than 24 hours with conservative line of management and must be switched over to operative management. Stage III (LRINEC scoring $\geq 8$ ) cases straight away need early aggressive operative line of management ranging from simple fasciotomy to aggressive repeated wound debridement, vacuum assisted closed drainage and appropriate amputations followed by delayed wound closure or reconstructive and rehabilitative procedures [36-38]. Results of our study as compared with those of previous similar studies are shown in TABLE 11. Even though the clinical findings are the main criteria to suspect / diagnose NF, it is neither specific nor sensitive especially in early stages. In intermediate and late cases also the clinical findings are not reliable because they are altered due to conservative line of management already given. LRINEC scoring is recommended as standard diagnostic tool by many authors. It is sensitive but less specific. However, this is also unreliable in early cases and in cases treated conservatively. Imaging modalities like CT \& MRI are not cost effective in Indian scenario and not useful in early cases. Ultrasonography also may not be useful in early cases. Gas in soft tissue X-ray is seen in $40 \%$ of cases only. Infra red spectroscopy to assess the oxygen saturation level in soft tissues under question as a tool for early diagnosis of NF is not documented well. With reference to wound swab and needle aspirate for culture \& sensitivity, negative culture does not rule out NF. Similar scenario is with biopsy. Bedside finger test is more specific. In early case, it may be negative. However, repeat finger test during continuous monitoring period might prove to be useful. Extensive literature review does not show any study suggesting definitive methods for early diagnosis. There is no study to suggest definitive protocol for emergency operative intervention, delayed operative intervention or conservative management. Only one detailed review article in 2014 by Goh T et al. [30] gives some idea on these lines.

Table 11: Results of our study as compared with those of previous similar studies

\begin{tabular}{|c|c|c|c|c|c|c|c|c|c|c|}
\hline & 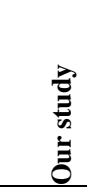 & 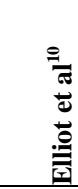 & 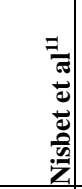 & 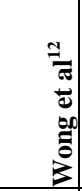 & 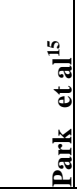 & 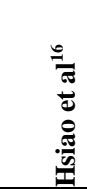 & 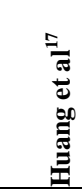 & 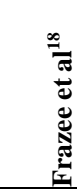 & 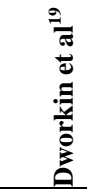 & 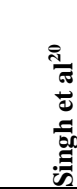 \\
\hline No.of patients & 12 & 98 & 2 & 9 & 17 & 28 & 72 & 22 & $\mathbf{0}$ & 5 \\
\hline Erythema & 100 & 6.3 & & 00 & 8.9 & 2.3 & $\mathbf{1 . 0}$ & 0.3 & 1 & 2 \\
\hline Warmth & 100 & & & 7 & & & 4.1 & & & \\
\hline Pain & 100 & 2.9 & 9 & 8 & 00 & 4.7 & 4.3 & 4.1 & 00 & 1 \\
\hline Swelling & 100 & 5.0 & 7 & & 9.7 & 1.1 & 3.7 & & 4 & 9 \\
\hline Bullae & 42.8 & 3.7 & 2 & 5 & 7.1 & & 3.3 & 1.5 & 1 & 5 \\
\hline Crepitus & 22.3 & 6.5 & & 4 & & & & .6 & 4 & 5 \\
\hline Skin necrosis & 38.3 & 1.1 & & 4 & & & & 3.8 & 9 & \\
\hline Fever & 32.1 & 1.6 & 4 & 3 & 1.8 & 3 & 0.1 & 4.3 & 6 & 7 \\
\hline Hypotension & & 1.1 & & 8 & 3 & 5 & 2.2 & 1.3 & $\mathbf{0}$ & \\
\hline Gas on x-ray \% & 47 & 7.4 & & 7 & & & .9 & 2 & 4 & 6 \\
\hline $\begin{array}{l}\text { Lab data } \\
\text { reported }\end{array}$ & $\mathbf{Y}$ & & & & & & & & & \\
\hline Positive wound & 86.6 & 9.2 & & 2 & 2.7 & 7.3 & 0.9 & 2 & 5 & 7 \\
\hline
\end{tabular}


Early Diagnosis And Management Of Necrotizing Fasciitis

\begin{tabular}{|l|l|l|l|l|l|l|l|l|l|l|}
\hline culture & & & & & & & & & & \\
\hline No growth & 13.3 & 1.8 & & 8 & 7.3 & 2.7 & .1 & 8 & 5 & 3 \\
\hline Polymicrobial & 71.4 & 4.6 & 2 & 4 & .8 & 3.4 & 3.7 & 5.3 & 4 & 9 \\
\hline Monomicrobial & 15.1 & 5.4 & 8 & 8 & 6 & 3.4 & 7.2 & 6.7 & 1 & 9 \\
\hline Blood culture & - & & 8 & & 6.1 & 8.9 & 5.7 & & & \\
\hline
\end{tabular}

\section{V. conclusion}

The limitations of our study are: this is a retrospective study, the size of this study sample is small, and available data in the case sheets were not complete. To create appropriate evidence level for specific guidelines, larger prospective study is needed with set protocols with mandatory LRINEC scoring and 'bedside finger test' for early diagnosis and specific indications for treatment protocol for emergency operative intervention, delayed operative intervention and conservative management.

\section{Acknowledgements}

An acknowledgement section may be presented after the conclusion, if desired Authors duly thank the Medical Records Department of Mahatma Gandhi Medical College and Research Institute, Sri Balaji Vidyapeeth University, Pondicherry for cooperating in data collection for preparing this article.

Authors also acknowledge the immense help received from the scholars whose articles are cited and included in references of this manuscript.

\section{References}

[1]. Descamps V, Aitken J, Lee MG. Hippocrates on necrotising fasciitis. Lancet. 1994 Aug 20;344(8921):556.

[2]. Anaya DA, Dellinger EP. Necrotizing soft-tissue infection: diagnosis and management. Clin Infect Dis. 2007 Mar 1;44(5):705-10. Epub 2007 Jan 22.

[3]. Wilson B. Necrotizing fasciitis. Am Surg. 1952 Apr;18(4):416-31.

[4]. Jones J. United States Sanitary Commission. Surgical memoirs of the War of the Rebellion. New York, NY: Hurd and Houghton; 1871. Investigation upon the nature, causes and treatment of hospital gangrene as prevailed in the Confederate armies 1861-1865; pp. $142-580$

[5]. N. Eke, "Fournier's gangrene: a review of 1726 cases," BJS, 2000:87(6):718-28

[6]. Meleney Fl, "Hemolytic streptococcus gangrene," Arch Surg. 1924;9(2):317-64. doi:10.1001/archsurg.1924.01120080083007.

[7]. Soh CR, Pietrobon R, Freiberger JJ, Chew ST, Rajgor D, Gandhi M et al. Hyperbaric oxygen therapy in necrotising soft tissue infections: a study of patients in the United States Nationwide Inpatient Sample. Intensive Care Med. 2012 Jul;38(7):1143-51. doi: 10.1007/s00134-012-2558-4. Epub 2012 Apr 20.

[8]. Morgan MS. Diagnosis and management of necrotizing faciitis: a multiparametric approach. J Hosp Infect. 2010 Aug;75(4):249-57. doi: 10.1016/j.jhin.2010.01.028. Epub 2010 Jun 9

[9]. Nelson GE, Pondo T, Toews KA, Farley MM, Lindegren ML, Lynfield R, et al. Epidemiology of Invasive Group A Streptococcal Infections in the United States, 2005-2012. Clin Infect Dis. 2016 Apr 22. pii: ciw248. [Epub ahead of print]

[10]. Elliott DC, Kufera JA Myers RA. Necrotizing soft tissue infections. Risk factors for mortality and strategies for management. Ann Surg. 1996; 224:672-83.

[11]. Nisbet M, Ansell G, Lang S, Taylor S, Dzendrowskyj P, Holland D. Necrotizing fasciitis: review of 82 cases in South Auckland. Intern Med J. 2011Jul;41(7):543-8.doi:10.1111/j.1445-5994.2009.02137.x. Epub 2009 Dec 4.

[12]. Wong C, Chang HC, Pasupathy S, Khin LW, Tan JL, Low CO. Necrotizing fasciitis: clinical presentation, microbiology, and determinants of mortality. J Bone Joint Surg Am. 2003 Aug;85-A(8):1454-60.

[13]. Kalaivani V, Hiremath BV , Indumathi VA. Necrotising Soft Tissue Infection-Risk Factors for Mortality. J Clin Diagn Res. 2013; 7(8):1662-5. Published online 2013 Aug 1. doi: 10.7860/JCDR/2013/5535.3240.

[14]. Shiroff AM, Herlitz GN, Gracias VH. Necrotizing soft tissue infections. J Intensive Care Med. 2014 May-Jun;29(3):138-44. doi: 10.1177/0885066612463680. Epub 2012 Oct 29.

[15]. Wang YS, Wong CH, Tay YK. Staging of necrotizing fasciitis based on the evolving cutaneous features. Int J Dermatol. 2007 Oct;46(10):1036-41.

[16]. Park KH, Jung SI, Jung YS, Shin JH, Hwang JH. Marine bacteria as a leading cause of necrotizing fasciitis in coastal areas of South Korea. Am J Trop Med Hyg. 2009 Apr;80(4):646-50.

[17]. Hsiao CT, Weng HH, Yuan YD, Chen CT, Chen IC. Predictors of mortality in patients with necrotizing fasciitis. Am J Emerg Med. 2008 Feb;26(2):170-5. doi: 10.1016/j.ajem.2007.04.023.

[18]. Huang KF, Hung MH, Lin YS, Lu CL, Liu C, Chen CC et al. Independent predictors of mortality for necrotizing fasciitis: a retrospective analysis in a single institution. J Trauma. 2011 Aug;71(2):467-73; discussion 473. doi: 10.1186/1477-7819-6-67

[19]. Frazee BW, Fee C, Lynn J, Wang R, Bostrom A, Hargis C, et al. Community-acquired necrotizing soft tissue infections: a review of 122 cases presenting to a single emergency department over 12 years. J Emerg Med. 2008 Feb;34(2):139-46. Epub 2007 Aug 29.

[20]. Dworkin MS, Westercamp MD, Park L, McIntyre A. The epidemiology of necrotizing fasciitis including factors associated with death and amputation. Epidemiol Infect. 2009 Nov;137(11):1609-14. doi: 10.1017/S0950268809002532. Epub 2009 Apr 7.

[21]. Singh G, Sinha SK, Adhikary S, Babu KS, Ray P, Khanna SK. Necrotising infections of soft tissues--a clinical profile. Eur J Surg. 2002;168(6):366-71

[22]. Shimizu T, Tokuda Y. Necrotizing fasciitis. Intern Med. 2010;49(12):1051-7. Epub 2010 Jun 15.

[23]. Hakkarainen TW, Kopari NM, Pham TN, Evans HL et al. Necrotizing soft tissue infections: review and current concepts in treatment, systems of care, and outcomes. Curr Probl Surg. 2014 Aug;51(8):344-62. doi: 1067/j.cpsurg.2014.06.001. Epub 2014 Jun 12.

[24]. Tsai YH, Hsu RWW, Huang KC, Huang TJ. Laboratory indicators for early detection and surgical treatment of vibrio necrotising fasciitis. Clin Orthop Relat Res 2010;468(8):2230-37. 
[25]. Chao WN, Tsai SJ, Tsai CF, Su CH, Chan KS, Lee YT et al. The Laboratory Risk Indicator for Necrotising Fasciitis score for discernment of necrotising fasciitis originated from Vibrio vulnificus infections. J Trauma Acute Care Surg. 2012;73(6):1576-82. doi: 10.1097/TA.0b013e318270d761

[26]. Thomas AJ, Meyer TK. Retrospective evaluation of laboratory-based diagnostic tools for cervical necrotising fasciitis. Laryngoscope. 2012;122(12): 2683-87.

[27]. McHenry C R, Piotrowski J J, Petrinic D Malangoni M A. Determinants of mortality for necrotizing soft-tissue infections. Ann Surg. 1995 May;221(5):558-65.

[28]. Rouse TM , Malangoni MA, Schulte WJ. Necrotizing fasciitis: a preventable disaster. Surgery. 1982;92(4):765-70.

[29]. Andreasen TJ, Green SD, Childers BJ. Massive infectious soft-tissue injury: diagnosis and management of necrotizing fasciitis and purpura fulminans. Plast Reconstr Surg. 2001;107(4):1025-35.

[30]. Morgan MS. Diagnosis and management of necrotising fasciitis: a multiparametric approach. J Hosp Infect 2010;75(4):249-57.

[31]. Wong CH, Khin LW, Heng KS, Tan KC, Low CO. The LRINEC (Laboratory Risk Indicator for Necrotizing Fasciitis) score: a tool for distinguishing necrotizing fasciitis from other soft tissue infections. Crit Care Med. 2004;32(7):1535-41. doi: 10.1097/01.CCM.0000129486.35458.7D

[32]. Goh T, Goh LG,.Ang CH, Wong C.H. Early diagnosis of necrotizing fasciitis. BJS. 2014;101(1):e119-25.

[33]. Majeski J, Majeski E. Necrotising fasciitis: improved survival with early recognition by tissue biopsy and aggressive surgical treatment. South Med J. 1997;90(11):1065-8

[34]. Lancerotto L, Tocco I, Salmaso R, Vindigni V, Bassetto F. Necrotising fasciitis: classification, diagnosis, and management. J Trauma Acute Care Surg. 2012;72(3)560-6. doi: 10.1097/TA.0b013e318232a6b3

[35]. Kaul R, McGeer A, Norrby-Teglund A, Kotb M, Schwartz B, O'Rourke K et al. Intravenous immunoglobulin therapy for streptococcal toxic shock syndrome--a comparative observational study. The Canadian Streptococcal Study Group. Clin Infect Dis. 1999 Apr;28(4):800-7.

[36]. Assenza M, Cozza V, Sacco E , Clementi I , Tarantino B Passafiume F et al VAC (Vacuum Assisted Closure) treatment in Fournier's gangrene: personal experience and literature review. La Clinica Terapeutica, 2011;162(1):e1-5.

[37]. Steinstraesser L, Sand M, Steinau HU. Giant VAC in a patient with extensive necrotizing fasciitis. Int J Low Extrem Wounds. 2009 Mar;8(1):28-30. doi: 10.1177/1534734609331991. Epub 2009 Jan 28.

[38]. Kumar S, O'Donnell ME, Khan K, Dunne G, Carey PD, Lee J. Successful treatment of perineal necrotising fasciitis and associated pubic bone osteomyelitis with the vacuum assisted closure system. World J Surg Oncol. 2008 Jun 24;6:67. doi: 10.1186/1477-78196-67. 